\title{
Research on Individualized Teaching of College English from the Perspective of Humanism
}

\author{
Dang $\mathrm{Li}^{1, \mathrm{a}}$ \\ ${ }^{1}$ Xi'an peihua University, Xi'an, 710123, China \\ ${ }^{\mathrm{a}}$ email
}

Keywords: Individualized teaching, College English, Humanism

\begin{abstract}
The introduction of humanistic education into College English teaching in China provides theoretical guidance and practical direction for individualized teaching of College English. This paper explores the necessity of introducing humanism into College English, and points out the characteristics of the individualized teaching model of College English based on humanism, including diversified teaching materials, layered curriculum setting, innovative teaching form and individualized after-class tutoring to provide some references for the relative researchers.
\end{abstract}

\section{Introduction}

The core of humanism is people oriented, emphasizing the role and value of human beings. Modern humanism theory originates from American research in psychology, at the beginning of 1960s, the famous American psychologist Maslow and other people around the core requirements of the human potential, winter, creativity, value and meaning of life are fully studied. The influence of humanistic psychology, management, education in all aspects of it are further enhanced focus on people. The main theory of humanism including hierarchy of needs theory, self-realization theory, meaningful learning theory, the theory of hierarchy of needs that people need is the internal driving force of development, and human needs with different levels, from the physiological, safety, belonging and love, respect and understanding to the aesthetic and self-realization gradually, the theory of self-actualization is people will fully utilize and develop talent, ability and potential in the process of self-realization. Such a person seems to be doing his best to make himself perfect. Meaningful learning is closely related to learning content, learners' goals and environment. Thus, the nature and development of the theory of humanism concern, pay attention to the emotional needs of people, for the construction of College English textbooks, should pay attention to the cognitive characteristics, the needs of college students, emotional characteristics, subjectivity and give full play to the independent college in college students' English learning, to promote students' autonomous development, creation, the spirit of freedom according to the characteristics of college students, English learning, scientific and rational organization of teaching material construction, really stimulate students' meaningful learning, promoting college students' self-realization process. The humanistic value lies in the thinking paradigm can be a real breakthrough of rationalism, establish the reasonable position of psychological factors, the influence factors of learning interest and emotion of the excavated attention, so that the optimal effects of learning.

\section{Traditional Teaching Model of College English}

The traditional teaching mode of College English is a standardized teaching mode. Standardized College English teaching refers to the traditional mode of English teaching, and adopts the homogenization teaching method for all students. The teaching methods of teaching materials, strict regulations on the number of students, the number of the classes, teacher qualifications, training in all aspects of content and methods are made, or even what students participate in the English exam, at what time to have strict process. In this standardized College English teaching mode, we can achieve more equitable teaching and training. Students receive highly similar teaching content, and after class tutoring mode also take the way of listening, speaking, reading and writing, so that the unified 
provisions of teaching materials. But the teaching effect is very different. Some students test easy high scores, some students but every time thrilling low altitude flying. In this mode of teaching, students do not need to take the initiative, just waiting for the teacher according to the teaching plan to instill knowledge, in order to get a high score in the exam, only memories of the learned and ingenious combination of key classes. The result is that students develop into test machines rather than active learning. In addition, for teachers, standardized teaching model reduces the workload to some extent, but also improves the teaching difficulty. Because students are independent individuals after all, how to ensure that each student effectively absorb the teaching content under the premise of limited resources and limited methods has become the most headache problem for teachers. From the perspective of teaching objective, standardized teaching mode is to transfer knowledge unilaterally instead of the students' active learning ability is the ability of active or exploit their own advantages, resulting in students' lack of confidence and self-learning ability.

\section{Necessity of Introducing Humanism into College English Teaching}

At the same time, China's College English teaching continues to abandon the shortcomings of humanistic psychology, at the same time, take its essence, the system of scientific knowledge imparting and skills training into the personalized teaching of College English. In recent years, the research field of College English Teaching in China has paid close attention to personalized teaching. Personalized College English teaching mode is a new teaching mode formed under the guidance of humanistic education thought. Thus, personalized English teaching model should provide enough personalized space for students to choose their own learning methods and learning content, instead of just one size fits all. Pay attention to the difference between the student individualized teaching mode, organize students to participate in various learning activities and found their own strengths as a pathfinder and the role of teacher discipline maintenance, stimulate students' interest in learning. In this context, the training of students should be highly personalized, fully aware of their own, master a more scientific learning methods and ways, high learning initiative, good learning results of the compound talents. Humanistic education thought is composed of student view, teacher view and goal view under Humanistic Education thought. The student view of humanistic education mainly refers to regard students as independent and differentiated individuals, expecting students to be responsible for their own learning, rather than treating students as machines to accept educational knowledge. The teacher view of humanistic educational thought means that teachers act as facilitators and guides in the process of learning, rather than complete dictatorship and leadership. The teacher's main task is to create a comfortable learning environment for students, respect students, honest with the students. The humanism education thought to subvert the traditional concept of education, that the purpose of education is to tap the potential of students and learning interest, but not with learning knowledge or learning methods to guide students to self-perception, to adapt to the external environment, the establishment of student oriented education, train one heart, all-round development the students.

\section{Individualized Teaching Model of College English Based on Humanism}

Diversified Teaching Materials. At present, College English textbooks are divided into three levels of difficulty according to initial, middle and senior levels. Students can choose learning from their own level. Students can successfully pass the National College English proficiency test through the successful completion of intermediate difficulty textbooks. In content, each unit embodies a theme, listening, speaking, reading, writing, translation to cultivate students' comprehensive language ability. The content of the units is interrelated so that the language ability can be improved in the process of repetition. In use, the current college English teaching materials have changed the mode of almost all the contents in the past classroom teaching. After class exercises, various forms, rich content, part of the problem set for students after class discussion, submit a group report. The inculcation of cultural knowledge provides a broad space for further exploration; the recommendation of classical literary works or films enables students to learn music. These methods 
aim to fully tap the students' interest points, display the students' learning personality, and mobilize the enthusiasm of students' Autonomous learning. In addition to a single set of textbook design for students personalized teaching is fully considered, but also gradually change the College English textbooks only in listening and speaking, reading, writing and translating writing patterns is the key content of language teaching a single set of teaching materials, gradually to the teaching of language and culture and language teaching materials should be used into the teaching of College English for in the elective courses, students learn to use according to their own interests. The individualized teaching under the guidance of humanistic teaching ideology embodies the diversification of textbook compilation. Textbook compilation should be graded on difficulty and textbooks for students of different English proficiency should be compiled. If standardized teaching materials are unified, students' learning passion will be greatly reduced.

Layered Curriculum Setting. The embodiment of humanistic education concept in curriculum design lies in the secondary design. Universities can offer different levels of difficulty and level of English courses, students choose different courses according to their own level, to avoid high, not low, not on. As for students' ability assessment, the students' ability can be evaluated regularly at the beginning of the semester and in the semester, and the students' English proficiency is also understood. This not only has the guiding function for the student own course selection, also has the reference function to the curriculum change. In addition to the hierarchy of curriculum difficulty, the diversification of curriculum is also a hierarchical embodiment. English teaching consists of pure language teaching and cultural teaching. Colleges and universities can combine the two, set up language courses and cultural courses. Through the subtle influence of cultural courses, to improve students' interest and understanding of English learning, which is much higher than the repetition rate of purely mechanical language. Thirdly, modularization should be applied to the course of listening, speaking, reading and writing. Combine listening with speaking, combining reading and writing, instead of splitting it apart. Finally, we should make full use of many media teaching resources and combine the knowledge in the classroom with the network resources in the curriculum. After a certain period of the basic stage of education, students can guide the use of network resources to learn independently. Because the classroom time is limited after all, although try to be personalized, but it cannot achieve completely differentiated teaching. The most important thing is to develop students' awareness of autonomous learning. Therefore, teachers provide students with a series of resources in the curriculum, so that students can choose the direction they are interested in, and actively explore after class to further develop their personal advantages. Only by combining language learning with personal advantages can students' competitiveness be enhanced. The introduction of online courses injects new vitality into the traditional curriculum, and embodies the liberal idea of humanistic education in curriculum design.

Innovative Teaching Form. The teaching mode covers a wide range, mainly refers to the classroom teaching methods. The traditional teaching method is mainly one-way or two-way communication, and the humanistic education concept of teaching methods advocate multi-directional communication. To truly respect students, to believe in students, to create all conditions and opportunities, to promote students' learning, so that students can eventually achieve self-realization. The student-centered teaching is the promotion of personalized teaching. In recent years, teachers in Colleges and universities continue to introduce new methods in teaching. For example, under the guidance of TBLT, teachers carry out the establishment of the research group, group discussion, submit research papers and other teaching and research activities, and actively guide students to participate in teaching, the teaching of English life, inspire students' critical thinking and creative thinking, encourage students to actively learn, training students to discover and solve problems the ability to improve the quality of students in a relaxed and harmonious environment. Teachers pay attention to the emotional factors of students, strengthen the learning exchange with students, and learn the fruits of learning together, experience the joy of learning, and enhance the confidence of learning. In addition to task-based teaching method, the teacher's teaching should also be close to the students' life, try to guide the class discussion topics to students' daily life, such as tourism, food, community activities, dormitory civilization and so on. These students are familiar 
with the topic of establishing students' interest in learning English, and at the same time during the discussion can provide timely solutions to meet these, shoot two hawks with one arrow in daily life problems, let students get double development. The "human centered" teaching concept in the humanistic education concept takes full account of the personality of English learners, and is a scientific theory to guide individualized teaching. Students actively participate in this classroom interaction can improve their awareness of learning, while experiencing the completion of a task satisfaction, access to psychological rewards.

Individualized After-class Tutoring. The traditional after-school tutoring is based on the teacher as the main body, unified counseling mode. Under the guidance of humanistic concept, after class tutoring should reflect personalized characteristics. After-school tutoring can be combined with the characteristics of students, set up some individual tasks, such as teachers, campus tour guide to organize an English speaking, English writing contest and so on for the different character of different ability levels of students the task of. Through the class task and coaching the diversified and personalized, each student can choose their own way of love, each student can reflect their self-esteem and self-confidence, and students can be strengthened. In addition, can change the old mode of teachers who bear in counseling on the subject, to help each other or assistance mode. This not only can reduce the teacher's tutoring task, but also can enhance the students' feelings, and cultivate the students' sense of responsibility and self-confidence. Some students are relatively shy personality, even if there might not have to ask the teacher, but every day to get along well with our classmates will be admitted, then for such students, peer tutoring is more effective. Secondly, seniors will have a reverence of the discharge, the need to resolve the mystery between the two. Through the senior guidance, not only can solve the difficulties in learning, for psychological emotional distress, senior as a person can also provide practical suggestions.

\section{Conclusion}

To some extent, the introduction of humanistic educational ideas can effectively make up for the neglect of the "human centered" teaching concept in the traditional language teaching. The guiding role of humanistic education concept in the process of personalized teaching cannot be ignored. It liberates students from simple mechanical learning and enters meaningful, exploratory and full of surprise language learning process, which ultimately improves the overall efficiency of foreign language learning.

\section{References}

[1] Li Yanfang. Discussion on Humanism Teaching View and Its Enlightenment on College English Teaching [J]. Education Teaching Forum, 2017(38): 246-247.

[2] Gao Ruikuo. Study on the Cultivation of College English Students Pragmatic Competence from Humanity Care Perspective [J]. Journal of West Anhui University, 2012, 28(6): 142-145.

[3] Li Lihui, Liang Li. Individualized Instruction of College English Teaching from the Perspective of Humanistic Education [J]. Journal of Hebei United University (Social Science Edition), 2013, 13(4): 116-119.

[4] Qi Lei. On the Factors Affecting College English Individualized Teaching and Improvement Measures [J]. Overseas English, 2015(12): 31-32. 